\title{
STUDI SEDIMEN PADA ANAK SUNGAI SAKA KANAN DI DAS TENGGARONG KABUPATEN KUTAI KARTANEGARA
}

\section{Oleh: Rachmad Mulyadi, S.Hut *)}

\begin{abstract}
ABSTRAK :
Tenggarong watershed has several Sub-watershed. one of them Saka Kanan river basin that be one of the present environment quality depreciation. drainage basin knowable as good or bad conditon based on erosion level in surface soil and sedimentation level in river. This research aims to detect rate of flow water level, sedimet load pregnancy flies and load basis for will detect environment quality standard. Saka Kanan watershed as one of the Sub-watershed that will give sedimet and load base material towards Tengarong Watershed.

method survey field with watch closely and measures rate of river flow, take river water sample to at sedimet load analysis flies. as sedimentation determination and water quality analysis. Terba Station in has criteria resim water as big as 1,45\% that criteria very ugly while station bensamar as big as $6,95 \%$ also in category very ugly. sedimet load measurement result flies in Terban station sedimet load between 28.60-685 mg/l enter in good category up to very ugly. station bensamar has value between 37.50-725.75 mg/l enter in good category up to very ugly.
\end{abstract}

Keywords : River Flow Level, Sedimet load, Saka Kanan Watershed

*) Staf Pengajar pada Jurusan Manajemen Hutan - Fakultas Kehutan - Universitas Mulawarman. 


\section{PENDAHULUAN}

\subsection{Latar Belakang}

Kalimantan atau lazim juga disebut Borneo, sebuah pulau yang terbagi menjadi 3 negara, yaitu Malaysia, Brunei Darussalam dan Indonesia yang berada pada garis katulistiwa yang beriklim tropis. Borneo yang masuk dalam wilayah negara Indonesia, secara administratif terbagi menjadi 4 provinsi, yaitu Kalimantan Barat, Kalimantan Timur, Kalimantan Selatan dan Kalimantan Tengah dengan luas seluruhnya adalah $549.032 \mathrm{~km}^{2}$ atau $73 \%$ dari luas Borneo (Mackinnon dalam Nordin dan Harizajudin, 2006). Data tersebut sekitar $28 \%$ dari seluruh daratan Indonesia. Kalimantan berperanan penting dalam pengembangan ekonomi Indonesia dan merupakan salah satu penghasil devisa utama. Kekayaan ini bukan berasal dari produk industri, juga bukan dari hasil pertanian dan perkebunan, melainkan karena besarnya cadangan sumber daya alam: hutan, minyak, gas, batu bara, dan mineral-mineral lain.

Kalimantan memiliki kekayaan hutan yang berlimpah-ruah. Pada tahun 1968, Kalimantan ditaksir mempunyai 41.470 .000 ha hutan atau kira-kira $70 \%$ dari seluruh luas Kalimantan. Luas ini mencakup 34\% seluruh luas hutan di Indonesia. Menjelang tahun 1990, dengan basis data yang lebih baik, luas lahan di Kalimantan yang masih tertutup hutan hanya 34.730.000ha atau 63\%. Angka ini menunjukkan kehilangan hutan tujuh juta hektar selama dua puluh tahun (Nordin dan Harizajudin, 2006). Sasaran pembangunan adalah terciptanya kualitas masyarakat Indonesia yang maju dan mandiri. Pembangunan yang menyangkut berbagai bidang secara langsung dan tidak langsung menuntut pemanfaatan dan pemberdayaan sumberdaya alam yang ada secara optimal untuk memenuhi dan meningkatkan pendapatan devisa negara melalui pengembangan di sektor kehutanan, pertanian, pertambangan dan lain-lain. Peningkatan jumlah penduduk yang cepat akan berpengaruh pada pola pemenuhan kebutuhannya seperti bahan makanan, mineral, energi dan kebutuhan lain. Pemenuhan kebutuhan dengan memanfaatkan sumberdaya alam akan berpengaruh pada penurunan nilai sumberdaya alam yang ada baik secara kualitas maupun kuantitas. Beberapa tahun terakhir ini lebih cendrung mengalami pemunduran dari masa-masa tahun 90an. Panen raya yang semula dapat diadakan beberapa kali pada berbagai daerah sekarang agaknya lebih jarang diadakan. Belum lagi adanya 
pengurangan areal pertanian yang sudah beralih fungsi menjadi areal pertambangan batu bara turut menjadikan daerah ini mulai kehilangan identitasnya sebagai daerah sentra pertanian. Masalah yang sangat merisaukan masyarakat Kalimantan Timur adalah alih fungsi dari areal pertanian berubah menjadi areal pertambangan batu bara yang akhirakhir ini gencar dan sangat pesat terjadi. Batu bara atau sering juga di sebut-sebut sebagai emas hitam oleh banyak kalangan memang banyak terdapat di daerah yang termasuk di Kabupaten Kutai Kartanegara. Kenyataan bahwa emas hitam ini merupakan salah satu sektor pertambangan yang menyumbang sangat besar bagi PAD (pendapatan asli daerah) kabupaten ini karena memang sebagian besar dari sumber PAD berasal dari sektor pertambangan dan khususnya pertambangan batu bara (Zacksepari, 2008). Penurunan nilai sumberdaya ini salah satunya adalah penurunan nilai lahan akibat terjadinya proses erosi dan sedimentasi dari pemanfaatan lahan yang tidak sesuai dengan daya dukungnya. Pembukaan wilayah berhutan dengan berbagai tujuan misalnya untuk perluasan areal pertanian, pembalakan, dan pembukaan kawasan pertambangan merupakan sumber yang berdampak terhadap terjadinya erosi. Keadaan baik atau buruk daerah aliran sungai (DAS) dapat diketahui berdasarkan tingkat erosi pada tanah permukaan dan tingkat sedimentasi pada sungai.

DAS Tenggarong yang memiliki beberapa anak sungai yang salah satunya sungai Saka Kanan merupakan salah satu daerah yang sekarang ini telah mengalami penurunan nilai lingkungan. DAS tenggarong yang memiliki luas $\pm 31.546,978$ ha berdasarkan peta Rupa Bumi Indonesia lembar Tenggarong Tahun 1991 dengan lahan seluas $\pm 846,779$ ha $(2,7 \%)$ terbuka untuk penggunaan lahan tambang batubara. Hal ini disebabkan oleh adanya kegiatan pembukaan lahan bervegetasi untuk berbagai keperluan baik untuk perluasan areal pertanian dan pertambangan di DAS Tenggarong, sehingga akan mempengaruhi sub DAS-sub DAS yang ada di DAS Tenggarong. Permasalahan tersebut mendorong dilakukannya penelitian sedimentasi yang terjadi di Sub DAS Saka kanan.

\subsection{Perumusan Masalah}

Kerusakan lahan akibat berbagai perlakuan terhadap lahan yang tidak sesuai dengan daya dukung lahan dalam suatu DAS akan menurunkan produktivitas lahan dan fungsi ekologis DAS tersebut 
bagi daerah di sekitarnya. Degradasi kualitas lingkungan hidup sebagai akibat pemanfaatan sumber daya alam yang tidak terkendali dan tidak mengacu pada kondisi bioregion, sehingga mengurangi potensi sumber daya alam wilayah Kalimantan. Alih fungsi lahan yang tidak terkendali menjadi salah satu isu utama di Kalimantan, walaupun telah terdapat berbagai peraturan perundang-undangan tentang alokasi lahan, akan tetapi dalam pelaksanaannya masih terjadi penyimpangan di lapangan. Kondisi ini telah menimbulkan dampak negatif yang sangat berat dengan munculnya banjir dan menurunnya produktifitas pertanian rakyat, serta dampak sosial lainnya. Perkembangan pembangunan telah mempersempit vegetasi yang menutup permukaan tanah menjadi lapisan kedap air, sehingga meningkatkan air limpasan dan telah mengakibatkan erosi tanah yang berkelanjutan sehingga akan berdamapak pada pasokan sedimen di sungai dan dapat melewati ambang batas konsumtif masyarakat sekitar. Kandungan sedimen pada sungai merupakan salah satu indikator untuk menilai baik dan buruknya kondisi suatu DAS dan juga sebagai indikator visual air untuk layak konsumsi atau tidak. Pengukuran sedimentasi untuk mengetahui beban endapan layang (BEL) dan muatan dasar untuk dapat diketahui nilai baku mutu lingkungannya.

\subsection{Tujuan Penelitian}

Penelitian ini bertujuan untuk mengetahui debit limpasan air sungai, kandungan beban endapan layang (BEL) dan muatan dasarnya untuk mengetahui standar baku mutu lingkungan Sub DAS Saka Kanan sebagai salah satu anak sungai yang akan memberikan pasokan BEL dan muatan dasar terhadap DAS Tengarong.

\subsection{Manfaat Penelitian}

a) Sebagai bahan pertimbangan bagi penentu kebijakan dalam perencanaan wilayah khususnya di daerah penelitian.

b) Sebagai bahan usulan penyusunan pedoman pelaksanaan tindakan konservasi lahan.

c) Sebagai informasi data untuk peneliti selanjutnya dalam evaluasi dan arahan konservasi Lahan.

d) Sebagai penambah pustaka penelitian 


\section{TINJAUAN PUSTAKA}

2.1.Daerah Aliran Sungai dan Karakteristiknya

Daerah aliran sungai (Watershed) adalah sutu daerah dengan batasan faktor tofografi dan DAS-DAS disekelilingnya yang berfungsi sebagai pengumpul air dari jeluk hujan dan pelimpas air sungai di kawasan DAS tersebut (Hewlet, 1985). Sarief (1986) menyatakan bahwa DAS adalah suatu wilayah aliran yang mempunyai kemiringan lereng yang bervariasi dan dapat menampung jeluk hujan dimana air mnegumpul di sungai utama untuk kemudian mengalir ke lautsehingga menjadi satu kesatuan wilayah air. Seyhan (1995), menyatakan penentu karakteristik DAS dapat diaktegorikan ke dalam 3 faktor yaitu: faktor iklim, faktor lahan yang meliputi tofografi, tanah, geologi, dan geomorfologi, faktor yang ketiga adalah faktor vegetasi dan tata guna lahan. Karakteriktik DAS yang baik adalah jika semua faktor-faktor tersebut memberikan pengaruh dalam keadaan seimbang.

Air yang masuk ke dalam DAS dapat berupa aliran air permukaan, aliran bawah permukaan, aliran air bawah tanah dan aliran air sungai. Dibandingkan dengan air bawah permukaan dan air tanah, air sungai cenderung lebih keruh karena kandungan sedimen yang dapat berupa lumpur.

\subsection{Aktivitas Manusia dalam DAS}

Tanpa campur tangan manusia keadaan pada suatu ekosistem berada dalam suatu keseimbangan dinamis yang alamiah. Kehadiran manusia cenderung merubah keseimbangan dallam ekosistem tersebut.

Ekosistem hutan yang ada dala suatu DAS merupakan ekosistem yang sering yang menjadi gangguan manusia, yaitu : penebangan pohon dan pengankutan hasil hutan keluar hutan tanpa pengembalian yang cukup memadai. Selain itu juga sering terdapat pembukaan wilayah hutan tanpa ada pengetahuan dan kajian mendalam tentang kualitas lahan kawasan hutan yang bersangkutan (Hadipoernomo, 1992). Kecerobohan dalam pemanfaatan sumberdaya alamn tidak hanya berakibat hasilnya kurang optimal tetapi juga menimbulkan kerusakan-kerusakan secara kuantitas seperti banjir dan kekeringan. Kerusakan secara kualitas adalah penurunan nilai baku air bersih atau pencemaran air yang melewati ambang batas standar baku mutu kualitas. 
Menurut Chow (1964), aktivitas manusia seperti penebangan vegetasi penutuptanha pada pengolahan lahan, pertambangan, pembangunana permukiman, dan aktivitas lain dapat menyebabkan kerusakan serius pada kondisi alami lingkungan.

\subsection{Sedimentasi Pada Daerah Sungai}

Sedimentasi tidak dapat dipisahkan dari erosi khususnya pada daerah aliran sungai., karena sedimentasi merupakan salah satu bagian penting dari proses erosi yaitu terjadinya pengendapan dari bahan yang diangkut (eroded material) pada peristiwa erosi (Throeh, et al. 1980; Manan, 1977). Aipassa (1996) meyatakan bahwa tanah yang tererosi cepat atau lambat (tergantung faktor yang mempengaruhinya) akan terakumulasi di bagian bawah dari kai bukit serta didalam badan sungai yang biasanya dikenal dengan sebutan sedimen. Hamilton dan King (1992) menambahkan bahwa erosi di tempat (on-site) merupakan sebab terjadinya peristiwa sedimentasi. . kegiatan konversi hutan menjadi lahan terbuaka dan pertanian hampir selalu berakibat kenaikan hasil endapan, terutama selama pengkonversian dan sesudahnya.

Asdak (1995) mengemukakan bahwa sedimen dapat menyebabkan pendangkalan waduk, sungai, saluran irigasi, dan terbentuknya tanah-tanah baru di tepi dan di delta sungai. Chow (1964), menyatakan bahwa tidak semua material yang tererosi di suatu daerah aliran masuk kedalam badan sungai. Partikel-partikel tanah yang terlepas di areal yang datar, dengan sedikit atau tidaknya aliranm permukaan hanya akan bergerak sedikit saja atau dalam jarak yang pendek sehingga tidak sampai masuk ke badan sungai. Materilmaterail yang tererosiu di daerah yang memiliki kemiringan dapat terbawa ke dalam badan sungai dan terdeposit di dalamnya. Jumlah material yang terangkut dari sumber dimana terjadinya erosi dan sampai ke badan sungai disebut hasil sedimen (sediment yield).

Mekanisme angkutan sedimen yang bergerak di dalam sungaiterbagi ke dalam 2 golongan :

1. Suspended load (angkutan melayang / muatan suspensi), ialah partikel-partikel sedimen yang bergerak melayang di dalam air dan terbawa bersama aliran

2. Bed load (angkutan dasar / muatan dasar), ialah gerakan dari pertikel-partikel tidak jauh dari dasar sungai dan bergerak bergeser, menggelinding dan meloncat. 
Perbedaan lain yang dapat dilihat adalah muatan material dasar dan muatan hanyutan. Muatan materi dasar adalah muatan yang berasal dari material sungai itu sendiri, sedangkan muatan hanyutan merupakan transpor material yang berasal dari luar sungai tersebut (Linsley,et.al., 1986).

Philipus (1997), menyatakan bahwa tingkat angkutan melayang yang ada dalam sungai umumnya rendah pada daerah dengan kondisi hutan dan akan trus meningkat seiring pembukaan hutan yang mengurangi luas penutupan hutan. Peran penutup lahan seperti halnya hutan memiliki peranan sebagai penahan energi hujan yang bersifat erosif dan menghancurkan butir tanah sebagai bahan yang nantinya akan tersedimentasikan baik on-site ataupun masuk ke sungai.

Selain tenaga erosif hujan sedimen juga dapat berasal dari aktivitas manusia seperti pertanian, pertambangan, konstruksi, perumahan, dan perdagangan yang menghasilkan limbah-limbah seperti :

1. sedimen yang berasal dari kebakaran hutan karena ulah manusia atau secara alami, pembalakan dan lain-lain.

2. aliran pupuk kimia, pestisidas dan garapan tanah intensif

3. cairan asam mineraldan sedimen dari penambangan aktif atau bekas tumpahan minyak dan bahan beracun lainnya.

Berbagai bentuk sedimen yang bersifat kimiawi akan sangat berpengaruh kualitas air. Pencemaran air ini disebabkan oleh konsentrasi zat pencemar yang terdapat pada air dalam kurun waktu tertentu dimana konsentrasinya berada di luar kriteria dan standar kualitas air.

Beberapa parameter fisik yang dapat dijadikan acuan untuk meneliti kualitas air adalah :

1. turbiditas atau tingkat kekeruhan yang derajat dari kejernijhan yang dihasilkan dari bahan yang tidak terlarut seperti debu, tanah liat, bahan organik dan anorganik

2. nilai $\mathrm{pH}$, keasaman dan alkalinitas : nilai $\mathrm{pH}$ normal untuk kondisi netral adalah antara 6-8.

3. suhu: kenaikan suhu air akan memicu reaksi kimia, jumlah oksigen terlarut dalam air menurun dan organisme seperti ikan akan terganggu.

4. Oksigen terlarut merupakan indikator dari kesesuaiaan bagi habitat organisme akuatik. 


\section{METODE PENELITIAN}

Metode yang digunakan adalah metode survey lapangan dengan mengamati dan mengukur debit limpasan, mengambil sampel air sungai untuk di analisis beban endapan layang (BEL) sebagai penentuan sedimentasi dan analisis kualitas air. Untuk penghitingan muatan dasar dilakukan prediksi sebesar 20\% dari BEL (Ilyas, 1987).

3.1.Penghitungan debit limpasan air sungai.

Metode yang digunkan adalah mid section

\section{$Q=$ d1.v1 $(b 1+b 2) / 2+$ d2.v2 $(b 2+b 3) / 2+\ldots \ldots \ldots \ldots \ldots+$ dn.vn $(b n+b(n+1)) / 2$}

Dimana :

$\mathrm{Q}$ : debit limpasan air sungai $\left(\mathrm{m}^{3} /\right.$ detik)

$\mathrm{v} 1, \mathrm{v} 2 \ldots . . \quad$ : kecepatan aliran tiap segmen $(\mathrm{m} /$ detik $)$

di,d2.... : : kedalaman air tiap segmen (m)

$\mathrm{b} 1, \mathrm{~b} 2 \ldots . . \quad$ : lebar tiap segmen $(\mathrm{m})$

\subsection{Indeks resim air}

Fluktuasi debit aliran ditentukan untuk menghitung resim air sebagi pembanding indeks resim air baku mutu lingkungan. Resim air dihitung dengan rumus (Fandeli, 1995) :

Indeks resim air $=(\mathrm{Qmin} / \mathrm{Qmax}) \times 100 \%$

Indeks resim air $=\left(Q_{\min } / Q_{\max }\right) \times 100 \%$

Tabel 1. Nilai indeks resim air baku mutu lingkungan

\begin{tabular}{|c|c|l|}
\hline No & Indeks resim air $(\%)$ & \multicolumn{1}{|c|}{ kriteria } \\
\hline 1 & $>80$ & Sangat baik \\
\hline 2 & $60-80$ & Baik \\
\hline 3 & $40-60$ & Sedang \\
\hline 4 & $20-40$ & Jelek \\
\hline 5 & $<20$ & Sangat Jelek \\
\hline
\end{tabular}

Sumber: Fandeli, 1995

3.3. Debit Endapan layang (BEL)

Konsentrasi BEL dihitung dengan rumus (Chow, 1964):

$$
\mathrm{Cs}=(\mathrm{q} 2-\mathrm{q} 1) / \mathrm{V}
$$


Dimana :

Cs = konsentrasi BEL $(\mathrm{mg} / \mathrm{l})$

q1 = berat kering kertas saring $(\mathrm{mg})$

q2 = berat kering BEL dan kertas saring $(\mathrm{mg})$

$\mathrm{V} \quad$ = volume air sampel (1)

Tabel 2. Standar Baku Mutu Lingkungan BEL

\begin{tabular}{|c|c|l|}
\hline No & BEL $(\mathrm{mg} / \mathrm{l})$ & \multicolumn{1}{|c|}{ kriteria } \\
\hline 1 & 0 & Sangat baik \\
\hline 2 & $0-100$ & Baik \\
\hline 3 & $100-250$ & Sedang \\
\hline 4 & $250-500$ & Jelek \\
\hline 5 & $>500$ & Sangat Jelek \\
\hline
\end{tabular}

Sumber: Fandeli, 1995

\section{HASIL DAN PEMBAHASAN}

Sungai Saka Kanan merupakan anak Sungai Tenggarong dimana sungai tersebut melalui kota Tenggarong, Kabupaten Kutai Kartanegara provinsi Kalimantan Timur. daerah penelitian termasuk dalam Formasi Pulau Balang dan Formasi Balikpapan. Jenis tanah di daerah penelitian adalah jenis podsolik merah kuning, yaitu tanah dengan horizon $\mathrm{B}$ berwarna merah kekuninganhingga merah kecoklatan, dengan kedalaman tanah kurang dari 1,5 m. Iklim termasuk dalam tipe B dalam klasifikasi iklim Schmidt dan Ferguson (1951). Tipe B adalah tipe daerah basah mempunyai jeluk hujan tinggi dengan vegetasihutan hujan tropik.

Hasil penelitian menunjukkan bahwa debit limpasan air sungai pada stasiun Terban berkisar antara 0.01-0.69 $\mathrm{m}^{3} /$ detik $\left(\mathrm{Q}_{\text {ratan }}=\right.$ $0.26 \mathrm{~m}^{3} /$ detik).pada stasiun Bensamar antar 0.27-3.88m3/detik ( $\mathrm{Q}_{\text {rataan }}$ $=1.95 \mathrm{~m}^{3} /$ detik). Menurut martha (1982) kondisi yang mempengaruhi nilai debit limpasan air sungai adalah faktor meteorologi yang terdiri dari jenis presipitasi, intensitas curah hujan dan distribusi hujan dalam DAS. Pada stasiun Terban memiliki kriteria resim air sebesar 1,45\% yang artinya berkriteria sangat jelek sedangkan stasiun Bensamar sebesar 6,95\% juga dalam kategori sangat jelek.

Hasil pengukuran beban endapan layang pada stasiun Terban adalah antara 28.60-685 mg/l masuk dalam kategori baik hingga 
sangat jelek. Stasiun Bensamar memiliki nilai BEL berkissar 37.50$725.75 \mathrm{mg} / \mathrm{l}$ masuk dalam kategori baik hingga sangat jelek.

Berdasarkan hasil analisis hubungan antar debit air dengan BEL adalah positif dengan korelasi sebesar 0.15 pada stasiun Terban dan 0.07 pada stasiun Bensamar. Rendahnya nilai-nalai korelasi ini diduga karena pada periode-periode tertentu tingginya konsentrasi BEL tidak diikuti oleh besarnya debit air. Hal ini dimungkinkan adanya ketersediaan sedimen tersebut yang terangkut bersama aliran air sungai. Menurut Hardwinarto (1996), bahwa pada saat-saat tertentu massa sedimen layang di saluran sungai tergantung pada jumlah bahan endapan yang tercuci oleh limpasan permukaan.

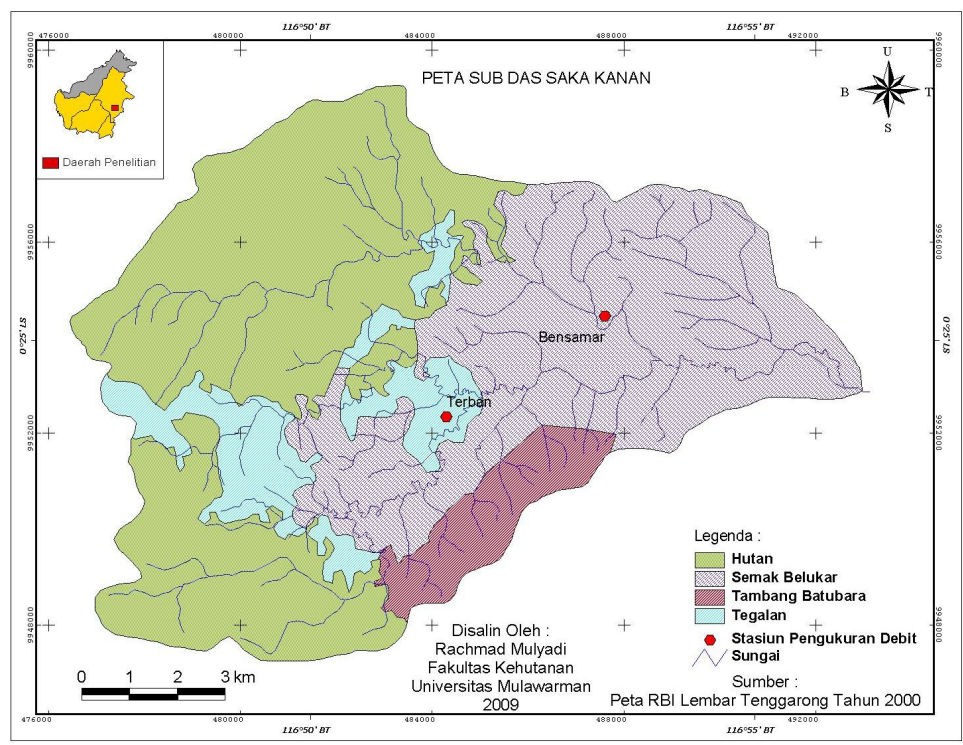

\section{KESIMPULAN DAN SARAN}

5.1. Kesimpulan

1. Debit limpasan air sungai pada stasiun Terban berkisar antara 0.01-0.69 $\mathrm{m}^{3} /$ detik $\left(\mathrm{Q}_{\text {ratan }}=0.26 \mathrm{~m}^{3} /\right.$ detik $)$.pada stasiun Bensamar antar 0.27-3.88m3/detik $\left(Q_{\text {rataan }}=1.95 \mathrm{~m}^{3} /\right.$ detik $)$.

2. Pada stasiun Terban memiliki kriteria resim air sebesar 1,45 $\%$ yang artinya berkriteria sangat jelek sedangkan stasiun Bensamar sebesar 6,95\% juga dalam kategori sangat jelek.

3. Hasil pengukuran beban endapan layang pada stasiun Terban adalah antara 28.60-685 mg/l masuk dalam kategori baik hingga sangat jelek. Stasiun Bensamar memiliki nilai BEL 
berkissar 37.50-725.75 mg/l masuk dalam kategori baik hingga sangat jelek.

\subsection{Saran}

Perlu adanya penanganan yang serius khususnya revegetasi kawasan bekas tambang batubara dan daerah hulu yang gundul sehingga dapat mendukung pemulihan kondisi daur hidrologi pada daerah tangkapan air Saka Kanan.

\section{DAFTAR PUSTAKA}

Aipassa.M.I. 1996. Konservasi Tanah dan Air. Program Magister Ilmu Kehutanan Universitas Mulawarman .Samarinda.

Asdak, C. 1995. Hidrologi dan pengelolaan daerah aliran sungai. Gadjah Mada University Press. Yogyakarta

Chow, V.T. 1964.Handbook of Applied Hidrology. Mc Graw Hill Book Company. New York.

Hamilton,L.S. dan P.N. King. 1992. Daerah Aliran Sungai Hutan Tropika (Terjemahan Suryanata, K). Gadjah Mada University Press. Yogyakarta

Hardwinarto, S. 1989. Water Quality Observation at Karang Mumus Watershed in Samarinda, East Kalimantan. GFG-Refort No. 13 Indonesian-Germany Forestry Project (IGFP). Samarinda

Hewlet, J.D. 1985. Principles of Forest Hidrology. University of Georgia Press. Athens Georgia.

Ilyas, M.A. 1987. Pemantauan Kondisi Suatu DAS Berdasarkan Indikator Erosi/ Sedimen.

Martha. T. 1992. Mengenai Dasar-dsar Hidrologi. Nova . Bandung Zacksepari. 2008. Mengkritisi Berita Terbaru tentang Kecamatan Samarinda Seberang. Separiblogger. Kutai Kartanegara

Sarief, E.S. 1986. Konservasi Tanah dan Air. Pustaka Buana. Bandung.

Seta A.K. 1987. Konservasi Sumberdaya Tanah dan Air. Kalam Mulia. Jakarta 